\title{
Effect of environmental variations on sharks and other top predators in the deep Mediterranean Sea over the last 60 years
}

\author{
J. E. Cartes ${ }^{1, *}$, E. Fanelli ${ }^{1}$, D. Lloris ${ }^{1}$, J. Matallanas ${ }^{2}$ \\ ${ }^{1}$ ICM-CSIC Institut de Ciències del Mar, Passeig Marítim de la Barceloneta 37-49, 08003 Barcelona, Spain \\ ${ }^{2}$ Facultat de Ciències Universitat Autònoma de Barcelona, Bellaterra, Barcelona, Spain
}

\begin{abstract}
The deep Mediterranean, which is characterized by high thermohaline stability, has suffered important changes in the last century, but these have seldom been analyzed with regard to megafauna. Long-term changes in fish and decapod assemblages in the Balearic Basin (western Mediterranean) were analyzed after compiling (since 1952) the species compositions of hauls taken at depths of ca. 400 to $600 \mathrm{~m}$. Multidimensional scaling analysis (MDS) showed significant segregation between hauls performed in the period 1952-1964 and hauls taken later. MDS segregated hauls taken off Catalonia from those off the Balearic Islands. The most general change recorded was a drop in the occurrence of most of the dominant deep-sea chondrichthyans, especially the shark Etmopterus spinax. Environmental analyses (canonical correspondence analysis and BIOENV) suggested a direct relationship between increases in temperature and salinity in intermediate waters and the decline of deep-water sharks. Abundance of E. spinax also decreased with decreasing $\mathrm{O}_{2}$ in the Levantine Intermediate Water (LIW) that may be related to changes in LIW in the western Mediterranean since the 1950s. This is in addition to increased fishery effort as a factor explaining the drop in shark abundance. In other regions of the western Mediterranean subjected to fishery pressure, E. spinax is still dominant. We suggest that small changes, both anthropogenic and climatic, occurring in the temperature and salinity of deep-water masses since the 1950s in the Balearic Basin have changed the composition of fish (especially sharks due to their high vulnerability) and crustacean assemblages.
\end{abstract}

KEY WORDS: Balearic Basin $\cdot$ Megafauna $\cdot$ Environmental change

\section{INTRODUCTION}

Marine communities have experienced large changes on different time scales. At a paleoceanographic scale, benthic marine assemblages have often experienced gradual long-term changes (e.g. during several hundred thousand years in marine mollusks: Cintra-Buenrostro et al. 2002; in benthic assemblages in general: Kosnik 2005) related to climate and sea level oscillations. Changes have been recorded not only at various taxonomic levels but also in the composition of ecomorphological (trophic) groups (Kosnik 2005), indicating changes in the habi- tat and the ecological dynamics of benthic communities. We find examples of such changes in the Mediterranean Sea, including the massive extinction of benthic species during the Messinian salinity crisis (6.5 to 5 million yr ago), during which drying of the Mediterranean Sea occurred (Pérès 1985).

Marine ecosystems also experience changes at decadal time scales related to human impacts, as happened in the Mediterranean during the 20th century. Changes in dominant fish and invertebrates (crustaceans, jellyfish) have been found close to the Suez Canal (Spanier \& Galil 1991) after its opening in 1869. 'Lessepsian' fish (e.g. Saurida undosquamis 
and Upeneus moluccensis) and prawns (Penaeus japonicus and P. monoceros) have come to constitute up to $30 \%$ of the total trawl catches off the Israeli coast (Ben-Tuvia 1973, Galil 2004). Por (1971) predicted that the westward advance of the Lessepsian immigrants would be more pronounced after the damming of the Nile River by construction of the Aswan High Dam. Multiple human activities may simultaneously impact marine ecosystems, generating a multifactor effect in which the impacts of the factors are difficult to separate.

Fishery pressure is also a cause of changes in the composition of marine communities over short time scales, especially in vulnerable habitats (formed by sessile animals like corals: Fosså et al. 2002) and species (e.g. sharks: Ferretti et al. 2008, Maynou et al. 2011) and also in low-productivity habitats such as the deep sea. Deep-water ecosystems have low productivity in comparison with shallow water systems, and bathyal species generally have low turnover rates. As a consequence, decreases in the catch per unit effort (CPUE) and size of exploited deep-sea fish have occurred only a few decades after exploitation began (e.g. rattails Coryphaenoides spp.: Hopper 1995), even after the application of total allowable catches per area (e.g. Hoplostethus atlanticus off New Zealand: Koslow 1997). Only deep-sea fisheries that are managed by using relatively selective gear (e.g. longlines for Aphanopus carbo off Madeira), or by avoiding access to recruitment areas (e.g. the shrimp Aristeus antennatus: Cartes et al. 2004) have shown fewer symptoms of overexploitation. All of these induced changes are difficult to distinguish from natural variability (e.g. responses to short-term climatic changes associated with the North Atlantic Oscillation, NAO). Spatial variability must be considered when studying temporal changes in communities, since latitude and depth are important sources of variability in deep-sea systems (Gage \& Tyler 1991, Cartes et al. 2009a).

The deep Mediterranean, with its relatively strong thermohaline stability (e.g. near constant conditions of temperature (T) and salinity (S) of ca. $13^{\circ} \mathrm{C}, 38 \mathrm{psu}$ throughout the year below $150 \mathrm{~m}$ : Margalef 1985), has suffered important temporal changes. In the last $50 \mathrm{yr}$, one of the most important environmental changes was the warming and salinization of intermediate and deep waters (below $150 \mathrm{~m}$ ) in the western Mediterranean (Rixen et al. 2005, Vargas-Yáñez et al. 2009). Temperature changes distinctly accelerated starting about 1955 in the Levantine Intermediate Water (LIW) and Western Mediterranean Deep Water (WMDW), water masses distributed at ca. 150 to $600 \mathrm{~m}$ and from $600 \mathrm{~m}$ to the bottom, respectively
(Rixen et al. 2005). $\mathrm{T}$ and $\mathrm{S}$ increased by $0.12^{\circ} \mathrm{C}$ and $0.03 \mathrm{psu}$ in the deepest layers from 1959-1988/1989 (Béthoux et al. 1990, Rixen et al. 2005, Vargas-Yáñez et al. 2009). These changes may be linked to general climatic change (Williams 1998) and to damming of major rivers (Rohling \& Bryden 1992, Béthoux \& Gentili 1999) that reduced freshwater discharges into the Mediterranean. The damming effect was particularly important after construction of the Aswan Dam in 1964, which reduced Nile discharge and affected LIW hydrological properties at its formation site in the Eastern Basin (Skliris \& Lascaratos 2004). LIW penetrates in the western Basin at $\mathrm{T}>13.5^{\circ} \mathrm{C}$ and $\mathrm{S}>$ 38.5 psu (Ghidalia \& Bourgois 1961, López Jurado et al. 2008), along with some variability in both $\mathrm{T}$ and $\mathrm{S}$ (Font 1987, Emelianov et al. 2006).

Analyses of the possible effects of these changes in the ecology of the deep Mediterranean Sea have only been attempted recently, revealing the local extinction/reduction in abundance of some commercial shrimps (Aristaeomorpha foliacea: Cartes et al. 2011a,b; Aristeus antennatus: Cartes et al. 2011a) in the second half of the 1960s in the Balearic Basin. However, there has been no analysis of deep assemblages at depths occupied by the LIW and WMDW. Our main objectives here were (1) to analyze longterm changes in the composition of deep-water communities of fish and decapod crustaceans in the Balearic Basin since the 1950s; (2) to test possible relationships between these changes and environmental conditions, with special emphasis on changes in $\mathrm{T}$ and $\mathrm{S}$ of the LIW; and (3) to analyze long-term changes in the frequency of occurrence of some vulnerable species (e.g. sharks and other chondrichthyans) within these communities. We discuss possible influences of environmental changes on deep-sea communities, bearing in mind the fishery effort.

\section{MATERIALS AND METHODS}

\subsection{Dataset}

\subsubsection{Biological sampling}

We compiled the species composition (number) of fish and decapods of 88 hauls performed at depths of 350 to $650 \mathrm{~m}$ off the Catalonian coast and around the Balearic Islands, and used literature sources for data from 15 hauls in the period 1950s-1964. Another 73 hauls were from our own datasets, performed between 1972 and 2007. Characteristics of these 73 bottom trawls were 13 hauls performed in 3 fishing grounds 


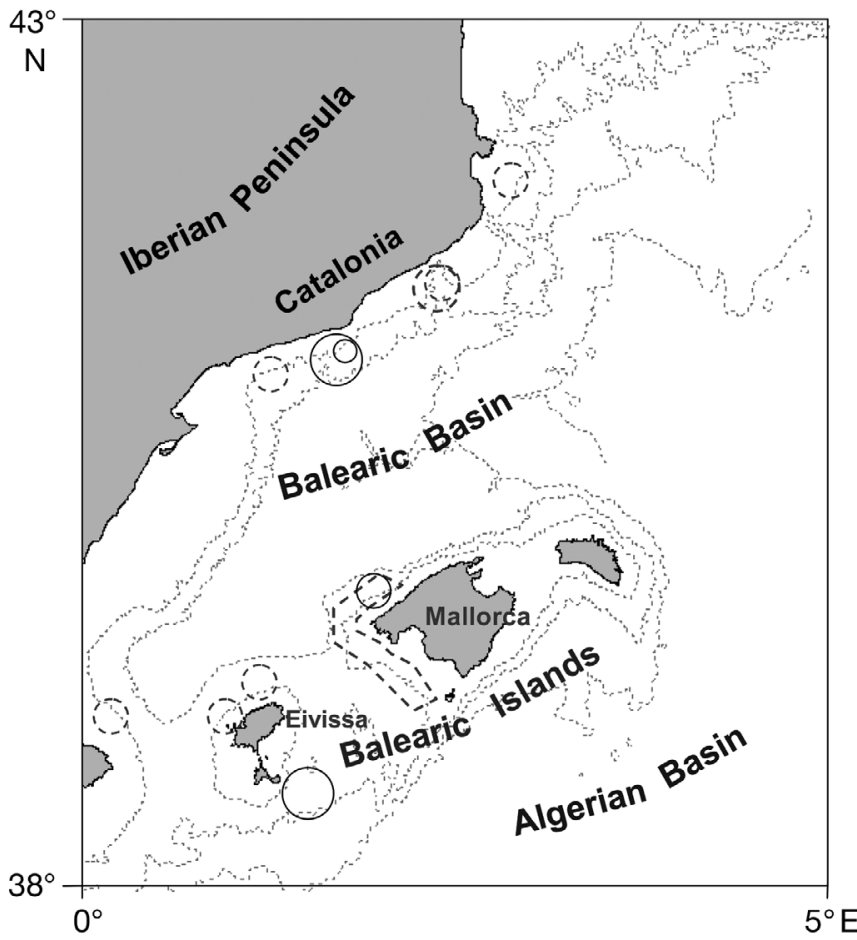

Fig. 1. Study area, showing the sampling sites (circles and polygon) in the periods $1950 \mathrm{~s}-1970$ s (dashed) and 1980s2007 (black)

(La Melica, El Sot de La Gamba, and La Barana) off Blanes $\left(41^{\circ} 07^{\prime} \mathrm{N}, 2^{\circ} 03^{\prime} \mathrm{E}\right)$ at depths between 250 and $600 \mathrm{~m}$ in 1972, 1973, and 1974 (Matallanas 1975); 13 hauls performed on board RV 'Cornide de Saavedra' in March 1977 from Catalonia (depths: 360-560 m) to Eivissa (Ibiza in Spanish; depths: 320-550 m) (Fig. 1; also see Suau 1981); 26 hauls from 4 fishing grounds (El Buscarró, Serola, Can Pere Negre, Clot de Sant Salvador) off Barcelona (between $40^{\circ} 08^{\prime}$ and $41^{\circ} 03^{\prime} \mathrm{N}$, $1^{\circ} 56^{\prime}$ and $2^{\circ} 13^{\prime} \mathrm{E}$ ) in 1988, 1989, 1990, and 2007 (Cartes 1994, Cartes et al. 1993); 13 hauls off the west of Mallorca (between $39^{\circ} 45^{\prime}$ and $38^{\circ} 40^{\prime} \mathrm{N}, 2^{\circ} 25^{\prime}$ and $\left.2^{\circ} 30^{\prime} \mathrm{E}\right)$ monthly from October 1996 to December 1997 (Moranta 2007); and 8 hauls taken in May 1996 in the southeast of the Balearic Islands (QUIMERA 1 cruise) on board RV 'Garcia del Cid' (Cartes et al. 2001) at fixed stations between 335 and $601 \mathrm{~m}$.

\subsubsection{Limitation of available data}

Before the 1970s, information on fish and crustacean assemblages on the continental slope was restricted to the pioneer studies by Oliver (1953) and Massutí (1971) performed around Mallorca (Balearic Islands). The sampling and available data in these studies had some limitations.
The 5 bottom trawls performed in 1952-1953 were on board the commercial trawler 'Maroto' (between 09/10/1952 and 02/06/1953; dd/mm/yyyy) at depths between ca. 300 and $700 \mathrm{~m}$ (mainly 400 to $600 \mathrm{~m}$, though with imprecise sounding data taken with lead lines) to the south-SW of Mallorca. The species composition from those trawls was obtained $4 \mathrm{yr}$ after fishery exploitation of bathyal depths around the Balearic Islands had begun. Only 1 vessel operated at bathyal depths in 1948 and 2 in 1949, increasing to 5 vessels in 1952 (Oliver 1953). The list of species provided by Oliver (1953) represented 10\% (in biomass) of the total catch, the rest being commercial species, mainly the deep-sea shrimps Aristaeomorpha foliacea, Aristeus antennatus, and Parapenaeus longirostris, and some commercial fish (Merluccius merluccius, Lophius spp.). The by-catch was classified in the laboratory to species level, counting the numbers and measuring the sizes of specimens (Oliver 1953). In 1964, monthly samplings of megafaunal communities were performed by Massutí (1971) following the same methodology as Oliver (1953). Composition was obtained from similar depths based on the catches of a shrimp trawler. Information is available from 10 bottom trawls with trawl durations of ca. 8 to $10 \mathrm{~h}$, without precise locations of the hauls. However, we can assume they were performed over adjacent (interfluve) slopes, not in submarine canyons because of the technical difficulty of trawling in canyons in 1964.

Data from Matallanas (1975) and Moranta (2007) did not contain quantitative data for crustaceans; only the weights of commercial species (Moranta 2007) and a list of the dominant decapods by fishing ground (Matallanas 1975, Matallanas \& Moreno-Amich 1985). Massutí (1971) also provided some data for Plesionika spp. without differentiating species. As a consequence, analyses were performed for (1) total megafauna (including fish and mainly commercial decapods) using Spearman distance, a similarity measure based on rank (not abundance); and (2) only fish for canonical correspondence analysis (CCA), after standardization of catches to ind. ha ${ }^{-1}$. Numbers of decapods were estimated in ca. $30 \%$ of hauls by weight/ number (mean weight, $g$ ind. ${ }^{-1}$ ) conversion factors.

\subsubsection{Environmental data}

T and S at haul depth and at the LIW core were downloaded from the the MEDATLAS database at www.ifremer.fr/medar/ by Dr. M. Vargas-Yañez (Centro Oceanográfico de Fuengirola, Instituto Español 
de Oceanografía, IEO) for the area of the Balearic Basin. We selected for our analyses $\mathrm{T}$ and $\mathrm{S}$ at the depth nearest to that at which hauls were performed. Rhône flow data $\left(\mathrm{m}^{3} \mathrm{~s}^{-1}\right)$ were compiled for the years with biological sampling (from the Global Runoff Data Centre: www.bafg.de/GRDC/EN/Home/homepage_node.html). Annual NAO indices were downloaded from the Climatic Research Unit of East Anglia University (www.cru.uea.ac.uk).

\subsection{Statistical analyses}

\subsubsection{Assemblage compositions}

Species appearing fewer than 2 times in hauls were removed from all data matrices. Variations in species composition of the 88 hauls were examined by nonparametric multidimensional scaling (nMDS; Clarke \& Warwick 1995). To minimize heterogeneity from the use of different trawl types, we used Spearman's rank correlation as a similarity distance. Spearman correlation measures the statistical dependence among pairs of variables based on rank data, not on raw abundances. Spearman's coefficient is therefore useful in assessing the correlation between pairs of variables obtained using heterogeneous samplers (e.g. different trawl types), and it is less sensitive to outliers than Pearson's correlation (Legendre \& Legendre 1998).

Factors considered to explain the ordination of hauls were the period of sampling and the area (hauls taken on the continental versus insular slopes). Within the factor Period, 2 groups of hauls were analyzed (1952-1953 and 1964 versus the years from 1972-2007), taking as a criterion the significant drop in deep-sea shrimps in the area between both periods (in 1968-1969: Cartes et al. $2011 \mathrm{a}, \mathrm{b})$. We also contrasted hauls taken at the mainland slope of the Balearic Basin (off Catalonia, NE Iberian Peninsula) versus hauls taken around the Balearic Islands. Distance-based permutational multivariate analysis of variance (PERMANOVA, Anderson et al. 2008) was used to test differences among the assemblages (1) between the 2 periods, and (2) between the continental and insular areas. A 2-way model for both factors combined was not possible because no species composition data before the 1970s were available off Catalonia. Separate 1-way univariate factor analyses were performed for Period and Area. A permutational ANOVA was designed for multivariate analyses; however, it can also be used for univariate ANOVA. One-way analyses for period were also performed separately on data matrices from the Balearic Islands and off Catalonia. In the last case (in the absence of hauls in the 1950-1960s), the 2 periods compared were 1972-1977 versus 1988-2007.

We ranked species by decreasing frequency of occurrence (not abundance) for 2 periods off the Catalonian coast (1972-1977 and 1988-2007) and 2 periods around the Balearic Islands (1952-1953 and 1964 versus 1996-1997). Within each group, the percentage of abundance of dominant species was calculated.

\subsubsection{Analyses of possible environmental causes}

To identify possible causes of changes in slope assemblages, we examined relationships between species composition (the dependent variables) and the following possible explanatory variables:

(1) T and S at the haul depth and T and S at the LIW core (maximum of $\mathrm{T}$ and $\mathrm{S}$ in intermediate waters, e.g. between 300 and $600 \mathrm{~m}$ );

(2) the (annual) NAO index as a climate oscillation proxy;

(3) the Rhône River discharge (sum of flows from 1 to 3 mo before sampling), in $\mathrm{m}^{3} \mathrm{~s}^{-1}$. The Rhône has the highest runoff of all rivers in the study area, the northern-central Balearic Basin;

(4) trawling effort as adopted by Cartes et al. (2011a), where effort data derived from raw data (engine power per boat, in horse power, HP) were provided by Fishers' Associations. Total HP of boats per year was adopted as the effort measure.

Trawling effort was analyzed only off Catalonia.

$\mathrm{O}_{2}$ was not considered as an explanatory variable because complete data series were not available (e.g. off the Balearic Islands in 1996-1997). Therefore, $\mathrm{O}_{2}$ at the LIW core was tested (Spearman rank) only against the rank of abundance of Etmopterus spinax (the species showing the clearest tendency in our analysis) within each haul. In 51 cases, a value of $\left[\mathrm{O}_{2}\right]$ at the LIW was related with E. spinax rank abundance. In only 14 cases, $\left[\mathrm{O}_{2}\right]$ at the LIW core was taken simultaneously with hauls (in 1977 and 2007), and in 10 cases, $\left[\mathrm{O}_{2}\right]$ was obtained \pm 2 mo from the haul date (in 1989). In the remaining cases, $9\left[\mathrm{O}_{2}\right]$ data points were taken in the same year as the haul collection (1990), but 8 mo later, and in 18 cases, data were \pm 2 to $3 \mathrm{yr}$ from the haul date (in 1952 and 1972/74). Data were compiled from the MEDATLAS database and from Segura (2007) for 1970-2003 (CSIC cruises). 
The BEST (BIO-ENV) procedure was applied to identify those combinations of environmental variables that best matched the distribution of the whole biotic data (Clarke \& Ainsworth 1993). BEST is based on Spearman's rank correlation. Relationships were also tested by multivariate CCA (Ter Braak 1986). CCA relates the abundance of each species to each environmental variable, rather than with a combination of variables as BEST performs. For CCAs, we roughly standardized fish abundance considering the basic features of trawls (e.g. approximate horizontal aperture) and characteristics of trawling in each period. Hours of trawling were roughly estimated for operations performed in the 1950s-1970s after interviewing retired fishermen. CCA is useful for extracting environmental gradients from ecological data (Ter Braak \& Verdonschot 1995). Arrows in CCA plots represent explanatory variables and are proportional in length to their importance (Ter Braak 1986).

CCAs related abundance (ind. ha ${ }^{-1}$ ) of fish in (1) all hauls and (2) separately for hauls performed in the mainland and insular areas. These analyses were performed on 79 hauls (all data were log-transformed), after exclusion of 9 hauls at depths $<350 \mathrm{~m}$ to minimize the possible effect of depth.

\section{RESULTS}

MDS showed some degree of separation (Stress = 0.20) among hauls as a function of spatio-temporal factors (Fig. 2). The 2 tested factors, Period (comparing hauls from the 1950s-1960s to those from 1977-2007) and Area (comparing Balearic and Catalan hauls) were significant (1-way PERMANOVAs: for period, pseudo- $F=2.84 ; \mathrm{p}=0.04$; for area, pseudo- $F=4.97 ; \mathrm{p}=0.004)$. There was a significant trend grouping hauls performed in the periods 1952/53-1964 (B52, B53-B64, upper part of the plot) and those taken in 1988-1990 (grouped at the lower part). These last hauls (CS, CM) were from fishing grounds inside/close to submarine canyons off Catalonia, whilst the 1950s-1960s hauls cited above were from the Balearic Islands. The ordination of hauls as a function of Period occurred both in the Balearic and Catalan areas separately. In the Balearic area, hauls from 1952/53-1964 (B52, B53, B64) were separated in the upper part of the plot from those in 1977 and the 1990s (M2, Q1, and B97; 1-way PERMANOVA, pseudo- $F=3.48 ; \mathrm{p}=0.001$ ), grouped in the lowest part. Off Catalonia, the 1970s hauls (CS72/74, CM1-CM5, M1-M3, M6, M7, and M32) were separated (to the right) of the 1980s-1990s (CS1-

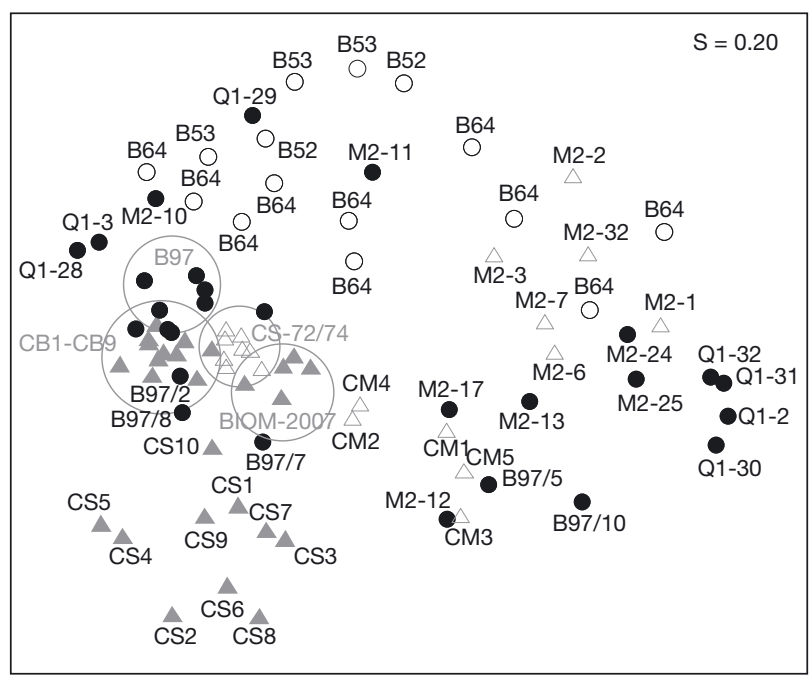

Fig. 2. Multidimensional scaling (MDS) of hauls performed in, and compiled from, the Balearic Basin (and neighboring areas): black symbols: around the Balearic Islands (1950s1960s: O; and 1990s: $)$ ); grey symbols: off Catalonia, in the Iberian Peninsula (1970s: $\Delta_{i}$ and 1980s-2007: $\Delta$ ). B52, B53, and B64 are hauls taken in the 1950s-1960s around Mallorca. M: MEDITERRANEO II cruise (March 1977); CS, CM: hauls performed over the Catalonian slope; Q1: Quimera 1 cruise (May 1996); B97: hauls taken in the Balearic Islands (NW Mallorca) in 1997; BIOM: BIOMARE cruises (2007) off the Catalonian slope; S: MDS stress

CS10; CB1-CB9) and 2007 (BIOM), hauls distributed to the left of plot (1-way PERMANOVA, pseudo- $F=$ 13.19; $\mathrm{p}=0.0001)$.

The rankings of the most abundant species, comparing the oldest (1950-1960s) and the most recent data obtained since the 1970s are shown in Table 1. In the 1950-1960s, Aristaeomorpha foliacea was the most abundant species (31\% of catches). Plesionika martia, Galeus melastomus, Aristeus antennatus, and Parapenaeus longirostris represented between 10 and $15 \%$, while Lepidorhombus boscii, Nephrops norvegicus, and Etmopterus spinax still accounted for $>3 \%$ of total individuals caught. After the 1970s, A. foliacea disappeared as a dominant species (Table 1), while sharks (G. melastomus, E. spinax) also fell in the ranking by about an order of magnitude. A. antennatus was largely dominant, comprising $53 \%$ of catches.

The most abundant deep sea chondrichthyans generally dropped in their frequency of occurrence (\%F) in catches (Fig. 3) after the 1970s. Except for Galeus melastomus, whose \%F increased in 1997 and 2007, the other species declined, especially Etmopterus spinax.

The BEST routine gave the best correlation between fish and decapod composition and a combination of the variables $\mathrm{T}, \mathrm{S}, \mathrm{T}$ and $\mathrm{S}$ at LIW $\left(\mathrm{T}_{\text {LIW }}\right.$ and 
Table 1. Ranking by decreasing order of abundance of fish (OST: teleosteans; CHO: chondrichthyans) and decapods (DEC) comparing abundances/occurrences in (1) the 19501960s and the 1970s-1990s off the Balearic Islands and (2) the 1970s and the 1980s-2007 off Catalonia. Cum\%: abundance within each period; \% F: frequency of occurrence

\begin{tabular}{|c|c|c|c|c|}
\hline & & Species & Cum\% & $\% \mathrm{~F}$ \\
\hline \multicolumn{5}{|c|}{ Catalonian coasts } \\
\hline \multicolumn{5}{|c|}{ Rank 1970s } \\
\hline 1 & $\mathrm{DEC}$ & Aristeus antennatus & 77.4 & 82.0 \\
\hline 2 & OST & Micromesistius poutassou & 2.4 & 100.0 \\
\hline 3 & OST & Phycis blennoides & 2.3 & 100.0 \\
\hline 4 & $\mathrm{DEC}$ & Pasiphaea multidentata & 1.4 & 100.0 \\
\hline 5 & OST & Merluccius merluccius & 1.1 & 100.0 \\
\hline 6 & OST & Lampanyctus crocodilus & 1.1 & 84.6 \\
\hline 7 & $\mathrm{DEC}$ & Plesionika martia & 1.0 & 100.0 \\
\hline 8 & OST & Gadiculus argenteus & 0.9 & 76.9 \\
\hline 9 & $\mathrm{CHO}$ & Etmopterus spinax & 0.8 & 92.3 \\
\hline 10 & OST & Trachyrincus scabrus $^{\mathrm{a}}$ & 0.7 & 100.0 \\
\hline 11 & $\mathrm{DEC}$ & Nephrops norvegicus & 0.5 & 76.9 \\
\hline 12 & $\mathrm{DEC}$ & Parapenaeus longirostris & 0.3 & 53.8 \\
\hline 13 & $\mathrm{CHO}$ & Galeus melastomus & 0.2 & 92.3 \\
\hline 19 & $\mathrm{DEC}$ & Aristaeomorpha foliacea & 0.1 & 76.9 \\
\hline \multicolumn{5}{|c|}{$1980 s-2007$} \\
\hline 1 & $\mathrm{DEC}$ & Aristeus antennatus & 82.6 & 100.0 \\
\hline 2 & OST & Phycis blennoides & 2.4 & 76.9 \\
\hline 3 & OST & Trachyrincus scabrus $^{\text {a }}$ & 2.3 & 61.5 \\
\hline 4 & OST & Micromesistius poutassou & 1.6 & 69.2 \\
\hline 5 & DEC & Pasiphaea multidentata & 1.4 & 100.0 \\
\hline 6 & $\mathrm{DEC}$ & Plesionika edwardsii & 1.2 & 38.5 \\
\hline 7 & $\mathrm{CHO}$ & Galeus melastomus & 1.0 & 69.2 \\
\hline 8 & $\mathrm{DEC}$ & Plesionika martia & 1.0 & 96.2 \\
\hline 9 & OST & Lampanyctus crocodilus & 0.8 & 92.3 \\
\hline 38 & $\mathrm{CHO}$ & Etmopterus spinax & $<0.1$ & 38.5 \\
\hline 52 & $\mathrm{DEC}$ & Aristaeomorpha foliacea & $<0.01$ & 7.7 \\
\hline \multicolumn{5}{|c|}{ Balearic Islands } \\
\hline \multicolumn{5}{|c|}{$1950 s-1960 s$} \\
\hline 1 & $\mathrm{DEC}$ & Aristaeomorpha foliacea & 31.2 & 53.3 \\
\hline 2 & $\mathrm{DEC}$ & Plesionika martia & 15.2 & 86.7 \\
\hline 3 & $\mathrm{CHO}$ & Galeus melastomus & 12.5 & 100.0 \\
\hline 4 & $\mathrm{DEC}$ & Aristeus antennatus & 10.9 & 73.3 \\
\hline 5 & DEC & Parapenaeus longirostris & 10.3 & 46.7 \\
\hline 6 & OST & Lepidorhombus boscii & 7.0 & 80.0 \\
\hline 7 & $\mathrm{DEC}$ & Nephrops norvegicus & 3.4 & 60.0 \\
\hline 8 & $\mathrm{CHO}$ & Etmopterus spinax & 3.1 & 100.0 \\
\hline 9 & OST & Lampanyctus crocodilus & 2.3 & 60.0 \\
\hline 10 & OST & Gadiculus argenteus & 1.8 & 53.3 \\
\hline 11 & OST & Phycis blennoides & 1.4 & 93.3 \\
\hline 12 & OST & Chlorophthalmus agassizii & 0.9 & 40.0 \\
\hline \multicolumn{5}{|c|}{ 1970s-1990s } \\
\hline 1 & $\mathrm{DEC}$ & Aristeus antennatus & 22.7 & 57.7 \\
\hline 2 & $\mathrm{DEC}$ & Plesionika martia & 11.0 & 69.2 \\
\hline 3 & $\mathrm{DEC}$ & Pasiphaea multidentata & 9.6 & 50.0 \\
\hline 4 & $\mathrm{DEC}$ & Nephrops norvegicus & 8.3 & 84.6 \\
\hline 5 & OST & Glossanodon leioglossus & 7.0 & 19.0 \\
\hline 6 & OST & Phycis blennoides & 6.9 & 100.0 \\
\hline 7 & $\mathrm{DEC}$ & Parapenaeus longirostris & 3.3 & 28.6 \\
\hline 8 & OST & Micromesistius poutassou & 3.2 & 84.6 \\
\hline 9 & $\mathrm{CHO}$ & Galeus melastomus & 2.7 & 100.0 \\
\hline 10 & OST & Lampanyctus crocodilus & 2.2 & 81.0 \\
\hline 26 & OST & Lepidorhombus boscii & 0.4 & 61.9 \\
\hline 32 & $\mathrm{CHO}$ & Etmopterus spinax & 0.3 & 71.4 \\
\hline 41 & $\mathrm{DEC}$ & Aristaeomorpha foliacea & 0.1 & 14.3 \\
\hline
\end{tabular}

$\mathrm{S}_{\text {LIW }}$ ), and NAO (Table 2). The variables depth, Rhône discharge, and fishery effort were not selected as explanatory variables in the most significant BEST models (Table 2). Similar results were obtained when fish compositions of Catalonia and the Balearic Islands were treated separately. Maximum $\rho$ values were 0.327 for Catalan fish assemblages and 0.386 for insular fish. $\mathrm{T}, \mathrm{T}_{\mathrm{LIW}}$, and $\mathrm{S}$ were the most recurring explanatory variables, while depth and Rhône discharge did not contribute to any BEST analyses. NAO only entered as an explanatory variable in some models for Catalonia and never in models of the insular area.

The CCA for the environmental variables $\mathrm{T}$ and $\mathrm{S}$ at haul depth, $\mathrm{T}_{\text {LIW }}$ and $\mathrm{S}_{\text {LIW }}$, NAO index, and Rhône discharge explained $63.9 \%$ of the total variance. Hauls taken in 1952/53 and 1964 (to the south-SW of Mallorca, included within plotted circles: Fig. 4) were located together in the left-upper part of the biplot, linked to the teleost Lepidorhombus boscii and to the chondrichthyans Chimaera monstrosa, Etmopterus spinax, and to a lesser extent to Galeus melastomus. These species were negatively correlated with S, both at depth of haul and at the LIW core above; that is, abundance decreased with higher $\mathrm{S}$. In the left-lower part of the biplot are hauls taken in the periods 1972-1974 and 1988-1990 off Catalonia. Some of these hauls (4 hauls from 1973-1974 and 4 from 1988) were positively but weakly (short vector length) correlated with the NAO index and with Epigonus denticulatus and the sharks Dalatias licha and Sciliorhynus canicula. Most hauls taken off Catalonia were located in submarine canyons (Foix and Blanes canyons), which would also explain the occurrence of $D$. licha. Finally, in the right part of the biplot, we found hauls from the 1970s-1990s taken mainly to the south-SW of the Balearic Islands and associated with the species Glossanodon leioglossus, Chlorophthalmus agassizi, and Hoplostethus mediterraneus. These hauls/species were negatively correlated with $\mathrm{T}_{\mathrm{LIW}}$ and negative NAO.

The CCA performed separately for Catalonia and Balearic slopes showed similar tendencies (Fig. 5; only species represented). In both areas, $\mathrm{S}$ at haul depth and at the LIW core and $\mathrm{T}_{\text {LIW }}$ were negatively correlated with the abundance of sharks: Etmopterus spinax and Dalatias licha off Catalonia, and all chondrichthyans (except $D$. licha) off the Balearic Islands. Some species of teleosts, mainly Merluccius merluccius and Gadiculus argenteus, showed the same tendencies in respect to $\mathrm{S}_{\text {LIW }}$ and $\mathrm{T}_{\text {LIW }}$ in both areas. Off Catalonia, the flatfish Lepidorhombus boscii was linked to high Rhône discharges. Off Catalonia, trawl- 


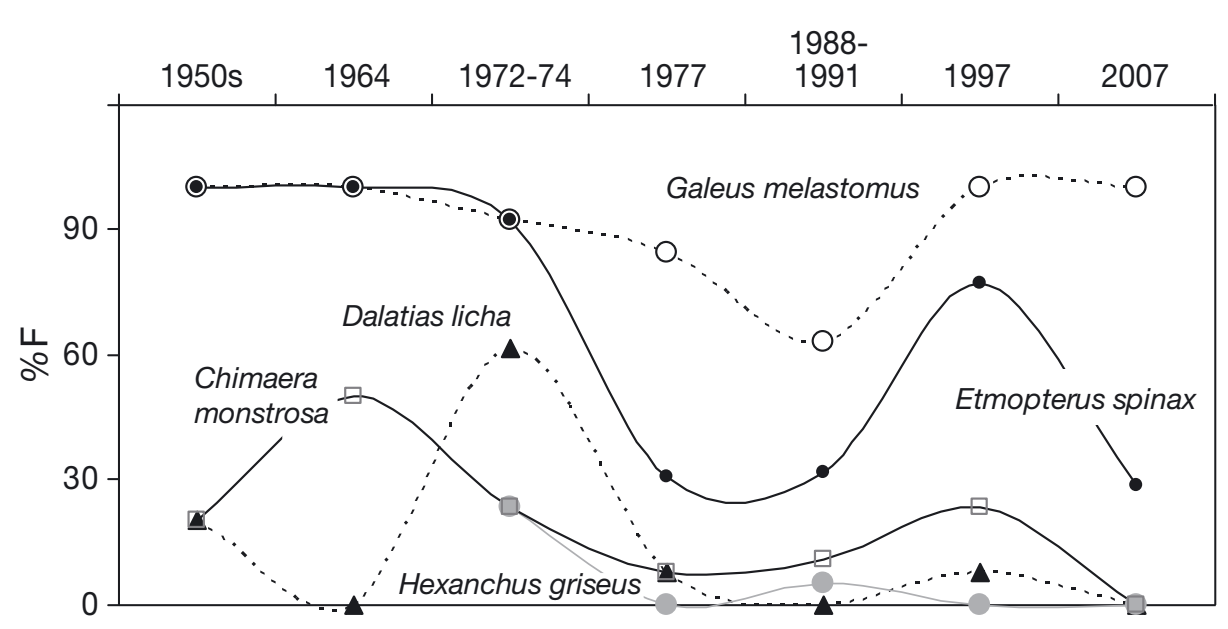

Fig. 3. Temporal trends in the frequency of occurrence $(\% \mathrm{~F})$ of the most abundant chondrichthyans in the Balearic basin and neighboring areas included in our sampling

ing effort was also negatively correlated with shark abundance in parallel to $\mathrm{S}$ (Fig. 5a). When CCA off Catalonia was repeated adding effort, variance was $37.1 \%$ at $\mathrm{F} 1$ and $30.4 \%$ at F2, very similar to results without effort. In general, the main explanatory variables suggested by CCAs coincided with those explaining species composition variability in BEST models.

Table 2. Results of BEST (BIOENV) procedure for the whole megafaunal assemblage, and for fish assemblages over the continental (Catalonia) and insular (Balearic Islands) slopes of the Balearic Basin. Only significant models matching at a maximum of 3 environmental variables with the biotic data (Spearman's $\rho$ ) were included. T: temperature; S: salinity; $\mathrm{T}_{\text {LIW }}\left(\mathrm{S}_{\text {LIW }}\right)$ temperature (salinity) at the Levantine Intermediate Water (LIW) core; NAO: North Atlantic Oscillation

\begin{tabular}{|c|c|c|c|}
\hline & No. var. & $\rho$ & Selected variables \\
\hline All taxa & 3 & 0.272 & $\mathrm{~T}, \mathrm{~T}_{\mathrm{LIW}}, \mathrm{NAO}$ \\
\hline \multirow{5}{*}{ (both areas) } & 2 & 0.272 & $\mathrm{~T}, \mathrm{NAO}$ \\
\hline & 3 & 0.272 & $\mathrm{~T}, \mathrm{~S}_{\text {LIW }}, \mathrm{NAO}$ \\
\hline & 2 & 0.272 & $\mathrm{~T}_{\text {LIW }}, \mathrm{NAO}$ \\
\hline & 3 & 0.272 & $\mathrm{~T}_{\text {LIW }}, \mathrm{S}_{\text {LIW }}, \mathrm{NAO}$ \\
\hline & 3 & 0.270 & $\mathrm{~S}, \mathrm{~T}_{\text {LIW}}, \mathrm{NAO}$ \\
\hline Fish & 3 & 0.386 & $\mathrm{~T}, \mathrm{~S}, \mathrm{~S}_{\mathrm{LIW}}$ \\
\hline (Balearic & 2 & 0.383 & $\mathrm{~T}, \mathrm{~S}$ \\
\hline \multirow[t]{7}{*}{ Islands) } & 3 & 0.365 & $\mathrm{~T}, \mathrm{~T}_{\mathrm{LIW}}, \mathrm{S}_{\mathrm{LIW}}$ \\
\hline & 2 & 0.364 & $\mathrm{~T}, \mathrm{~T}_{\mathrm{LIW}}$ \\
\hline & 3 & 0.364 & $\mathrm{~T}, \mathrm{~S}, \mathrm{~T}_{\text {LIW }}$ \\
\hline & 2 & 0.360 & $\mathrm{~T}, \mathrm{~S}_{\mathrm{LIW}}$ \\
\hline & 1 & 0.341 & $\mathrm{~T}$ \\
\hline & 1 & 0.311 & $\mathrm{~S}$ \\
\hline & 1 & 0.308 & $\mathrm{~S}_{\mathrm{LIW}}$ \\
\hline Fish & 3 & 0.327 & $\mathrm{~T}, \mathrm{~T}_{\mathrm{LIW}}, \mathrm{NAO}$ \\
\hline \multirow{5}{*}{ (Catalonia) } & 3 & 0.324 & $\mathrm{~T}, \mathrm{~S}, \mathrm{NAO}$ \\
\hline & 2 & 0.323 & $\mathrm{~T}, \mathrm{NAO}$ \\
\hline & 3 & 0.323 & $\mathrm{~T}, \mathrm{~S}_{\mathrm{LIW}}, \mathrm{NAO}$ \\
\hline & 2 & 0.312 & $\mathrm{~T}, \mathrm{~S}$ \\
\hline & 1 & 0.311 & $\mathrm{~T}$ \\
\hline
\end{tabular}

With respect to the possible influence of $\left[\mathrm{O}_{2}\right]$ at the LIW core on Etmopterus spinax abundance, we found significantly negative relationships between the rank occupied by this shark in hauls and $\left[\mathrm{O}_{2}\right]$ at LIW, based both on data collected simultaneously (Spearman $\rho=-0.703 ; p=0.005$ ) and on all compiled data $(\rho=-0.379 ; p=0.006)$.

\section{DISCUSSION}

\subsection{Limitations and assumptions of the study}

The use of historical data of species composition (fish and decapods) added some degree of uncertainty to our long-term analyses. We minimized this by adopting different criteria in compiling and analyzing the available data. Firstly, we compiled information on species composition exclusively obtained with commercial trawls. Species diversity varies at slope depths for both fish and decapods as a function of the trawl type used (Merrett et al. 1991, Cartes et al. 2009b), particularly as a function of its vertical height and the mesh size at the cod end (Cartes et al. 2009b), which affect species catchability. Our analysis was based on samplings almost exclusively performed with 2-warp trawls and mesh sizes at the cod end that were more homogeneous (between $17 \mathrm{~mm}$ in the 1950s and 32-40 $\mathrm{mm}$ at present) than in previous comparative studies (Merrett et al. 1991, Gordon \& Bergstad 1992, Cartes et al. 2009b). Despite their general similarity, characteristics of trawls used by fishermen changed over time in the Catalan Sea from trawls with vertical heights hardly exceeding $1 \mathrm{~m}$ in the 1950s to heights of 3-4 m in the 1990s (Bas et al. 1955, 2003). To minimize sampler heterogeneity, we 


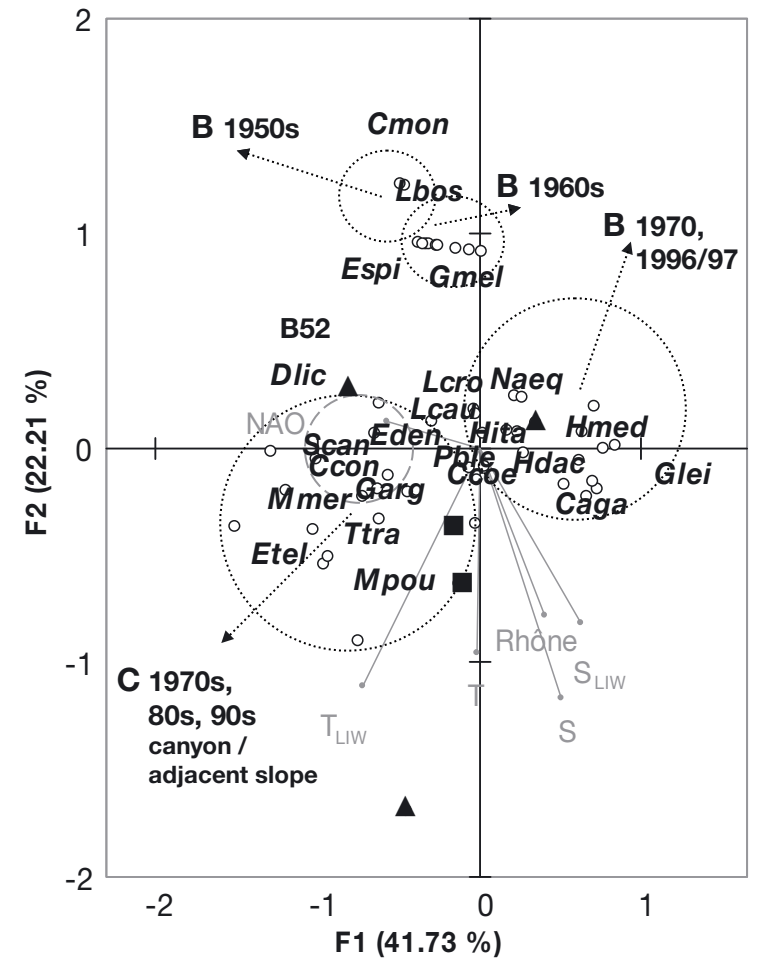

Fig. 4. Canonical correspondence analyses showing hauls and fish species relationships in the Balearic Basin and neighboring areas as a function of environmental (physical/ climatic) variables. Variable codes: T: temperature; $\mathrm{S}$ : salinity; $\mathrm{T}_{\text {LIW }}\left(\mathrm{S}_{\text {LIW }}\right)$ : temperature (salinity) at the Levantine Intermediate Water (LIW) core; Rhône: river flow; C: hauls taken off the Catalonian coasts; B: hauls taken off the Balearic Islands. Dotted circles include all hauls taken at those geographic areas and periods labelled, except some hauls taken at Catalan canyons $(\mathbf{\Delta})$ and around the Balearic Islands in the 1970s (ם). Species codes-Ccoe: Coelorinchus caelorhinchus (syn. C. coelorhynchus); Ccon: Conger conger; Cmon: Chimaera monstrosa; Dlich: Dalatias licha; Eden: Epigonus denticulatus; Espi: Etmopterus spinax; Etel: Epigonus telescopus; Garg: Gadiculus argenteus; Glei: Glossanodon leioglossus; Gmel: Galeus melastomus; Hdac: Helicolenus dactylopterus; Hita: Hymenocephalus italicus; Hmed: Hoplostethus mediterraneus; Lbos: Lepidorhombus boscii; Lcau: Lepidopus caudatus; Lcro: Lampanyctus crocodilus; Mmer: Merluccius merluccius; Mpou: Micromessistius poutassou; Naeq: Nezumia aequalis; Pble: Phycis blennoides; Scan: Scyliorhinus canicula; Ttra: Trachyrincus scabrus (syn. Trachyrhynchus scabrus)

analyzed our data comparing the frequency of occurrence of species (not abundance per swept area) among periods using Spearman's rank as a similarity distance (Legendre \& Legendre 1998). The only exceptions were the CCAs performed on fish densities. Fish abundances were more homogeneous (comparable) when using different trawl types than those of decapods. Because of their reduced size, some decapods (i.e. crangonids, galatheids) are poorly
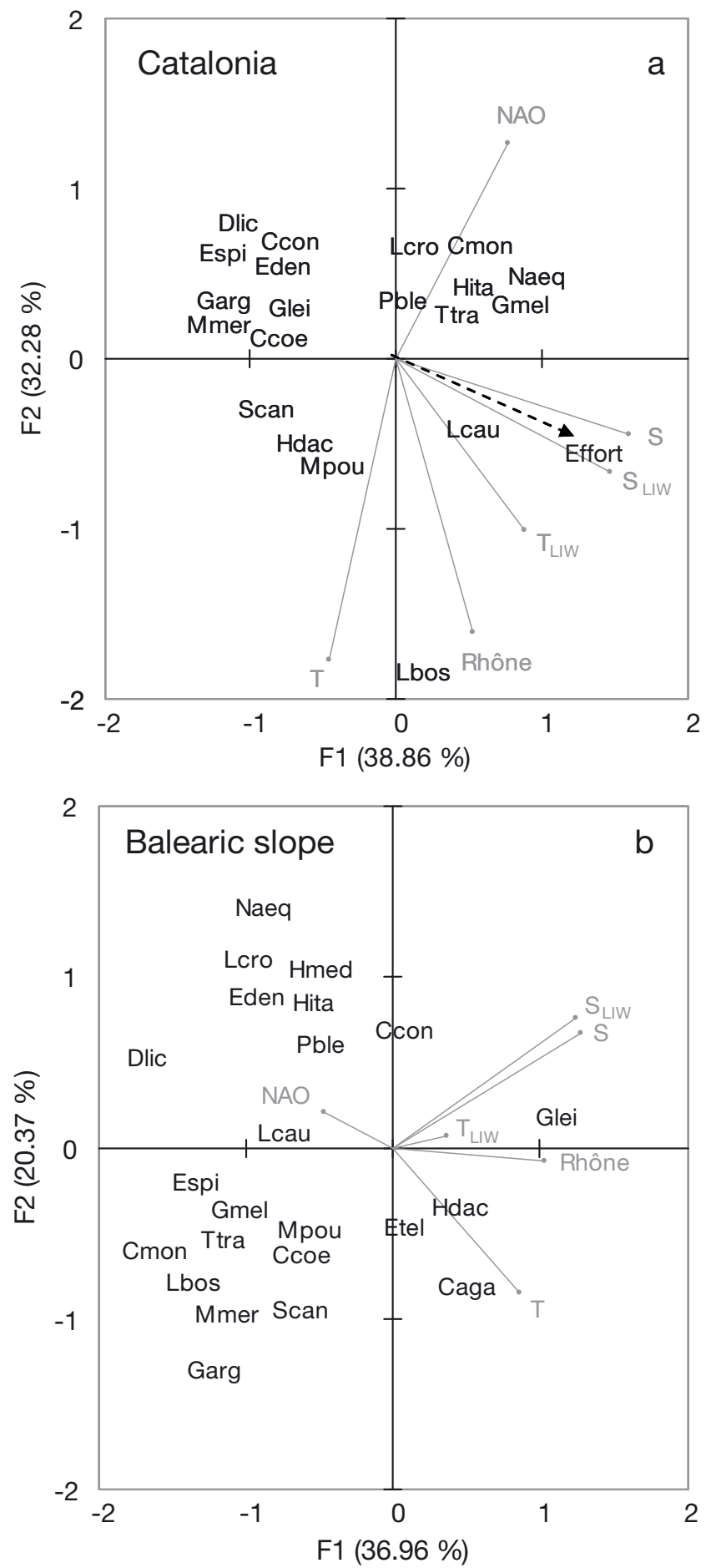

Fig. 5. Canonical correspondence analyses (CCAs) showing fish species relationships in the Balearic Basin and neighboring areas as a function of environmental variables over (a) continental (Catalonia) and (b) insular (Balearic Islands) slopes. Over Catalonia, a parallel CCA was performed adding effort as a variable with results very similar $(\mathrm{F} 1=$ $37.1 \%$ F $2=30.4 \%$ ) to those when only physical-climatic variables were considered. The arrow vector representing effort was superimposed on the CCA plot based only on physical-climatic variables. Species and variable codes as in Fig. 4 
captured by commercial trawls with large mesh sizes at the cod end (Cartes et al. 2009b).

We also found some taxonomic confusion in the studies from the 1950s-1960s, although the only one relevant was the citation of the shark Centrophorus granulosus as a dominant species off the Balearic Islands (Oliver 1953, Massutí 1971). This species was in reality Etmopterus spinax, a smaller shark. Oliver (1953) cited C. granulosus as a very abundant species in the Balearic Sea, represented by small individuals (always with a maximum size of $26.5 \mathrm{~cm}$ ). C. granulosus is a large species (to $150 \mathrm{~cm}$, common size range: 45-90 cm: D. Lloris unpubl. data) with very low fecundity (only 1 embryo female ${ }^{-1}$ : Tortonese 1956) and only occurring in hauls as 1 or 2 specimens. The fetus of C. granulosus is 33-35 cm (Capapé 1985), larger than the specimens cited by Oliver (1953). E. spinax was also cited on the Balearic slope (Maurin 1968) as a dominant species over Isidella elongata grounds (at depths of $500 \mathrm{~m}$ ), and it has been cited around the Balearic Islands more recently (Moranta 2007, Moranta et al. 2008).

\subsection{Changes in deep ecosystems and possible causes}

Chondrichthyans (e.g. sharks, rays) play an important role in maintaining the balance of marine ecosystems, because they are often top predators (Dulvy et al. 2008a). The global decline of large sharks (Myers \& Worm 2005) has been documented in coastal and pelagic ecosystems (Ferretti et al. 2008, Maynou et al. 2011) in the Mediterranean. Data on deep-sea systems are often insufficient for quantitative analysis (as in the case of Hexanchus griseus in Ferretti et al. 2008). Sharks play the same trophic role in the deep sea as in other systems, being at the top of trophic webs as documented by dietary studies (Carrassón et al. 1992, Carrassón \& Cartes 2002) and by stable isotope analyses (Polunin et al. 2001, Papiol et al. 2013). This is the case in the deep western Mediterranean for large Galeus melastomus and Etmopterus spinax that prey on fish and cephalopods (Carrassón et al. 1992), and for Dalatias licha preying on other sharks (Matallanas 1982). A high trophic level was deduced for these species based on $\delta^{15} \mathrm{~N}$ analyses: between 12.28 and $13.08 \%$ o for large specimens (highest $\delta^{15} \mathrm{~N}$ in slope fish community $=14.08 \%$; Polunin et al. 2001, Papiol et al. 2013).

The decline of top predators in marine ecosystems has been related to the increase in fishery effort (Hutchings \& Myers 1994, Ferretti et al. 2008). Factors other than fisheries have rarely been considered to explain drops in species abundance in open seas. For neritic (coastal) areas, some studies related changes in species composition to climatic (NAO) oscillations (e.g. for copepods: Molinero et al. 2005) and warming water masses (e.g. fish assemblages: Dulvy et al. 2008b). CCA results in the present study show an inverse relationship between positive NAO and low Rhône discharges. This is expected, since high NAO periods are linked to low rainfall episodes (and low river flows) in the western Mediterranean (Mariotti et al. 2002, Cartes et al. 2009a). Our analyses suggest a direct relationship between the increase in $\mathrm{T}$ and $\mathrm{S}$ at intermediate waters and the decline in deep-water sharks. This is a factor additional to the increases in fishery effort and (probably also) of efficiency in catching swimming species (e.g. sharks) by an increase in the vertical height of commercial trawls. T changed in the LIW at ca. 200 to $600 \mathrm{~m}$ (Font 1987), distinctly accelerating since the 1950s (Rixen et al. 2005). LIW arrives in the western Basin, producing intermediate maxima in $\mathrm{T}$ and $\mathrm{S}$ at ca. $400 \mathrm{~m}$ (Emelianov et al. 2006, López-Jurado et al. 2008). In the Balearic Basin, $T$ increased from $12.95^{\circ} \mathrm{C}$ in 1957 to $>13.40^{\circ} \mathrm{C}$ in the 1990 s and 2007 (compiled by Cartes et al. 2011b). S showed a similarly increasing tendency. In a parallel study, we have shown a local extinction of the shrimp Aristaeomorpha foliacea in the Balearic Basin (from 4 to 32 ind. ha ${ }^{-1}$ in 1950-1966 to <0.1 ind. ha ${ }^{-1}$ more recently, Cartes et al. 2011a). The decrease of $A$. foliacea in the Balearic Basin was linked to an increase of T (and S) in the LIW, which is distributed immediately above the shrimp's preferred habitat depth. This new analysis suggests that the whole assemblage of fish dwelling in intermediate waters could have had a similar response to environmental changes. Such changes in deep communities are independent of cascading events (episodic formation of dense cold waters arriving at great depths: Béthoux et al. 2002). Events of intense cascading of dense water from the shelf in the Gulf of Lions occurred in 1971, 1980, 1988, and 1999, affecting the hydrology of WMDW. Only one of those events (1988) coincided with our samplings. As discussed for the decline of A. foliacea and Aristeus antennatus in the Balearic Basin (Cartes et al. 2011a), changes found here in slope communities may be related to the observed warming and the reduction of freshwater input by river damming in the Mediterranean (Béthoux \& Gentili 1999). This response would be more identifiable among particularly vulnerable taxa (e.g. sharks) due to their slow growth, late age of maturity, and low reproductive rate (Myers \& Worm 
2005). Etmopterus spinax, for instance, is ovoviviparous with low fecundity and considerable longevity (ca. 20 yr: Coelho \& Erzini 2008).

In the deep Mediterranean Sea, only small seasonal oscillations in $\mathrm{T}$ and $\mathrm{S}$ occur below ca. $150 \mathrm{~m}$ (Margalef 1985). There must be, therefore, no adaptive value for deep-sea organisms in evolving wide temperature tolerance or strong osmoregulatory mechanisms. Accordingly, we hypothesize that small environmental variations (occurring, for instance, over decades) may be significant for species living in these habitats, as previously suggested for explaining the local extinction of Aristaeomorpha foliacea in the Balearic Basin (Cartes et al. 2011b). The increase of $\mathrm{T}$ and $\mathrm{S}$ in the LIW has been coupled with lower $\left[\mathrm{O}_{2}\right]$ (Kress \& Herut 2001, Roether \& Well 2001), which could especially influence species with high metabolic (or swimming) activity as hypothesized for A. foliacea. In the Catalan Sea, a linear drop in $\mathrm{O}_{2}$ was recorded at the LIW core $(\mathrm{r}=-0,87$; $\mathrm{p}<0.01, \mathrm{n}=$ 20: Segura 2007) between 1970 and 2003, with maximum $\mathrm{O}_{2}$ concentrations at the LIW core declining from 4.6-4.8 $\mathrm{ml} \mathrm{l}^{-1}$ to 4.0-4.2 $\mathrm{ml} \mathrm{l}^{-1}$ (Segura 2007). Our CTD data during 2007 confirmed this trend in the $\mathrm{O}_{2}$ at the LIW core, with a maximum $\mathrm{O}_{2}$ of $4 \mathrm{ml} \mathrm{l}^{-1}$ (ca. $55 \%$ of $\mathrm{O}_{2}$ saturation: Cartes et al. 2011b). This is below the $\mathrm{O}_{2}$ saturation estimated by the 'Thor' expedition (Nielsen 1912) of $76 \%\left(5.8 \mathrm{ml} \mathrm{l}^{-1}\right)$ at depths of maximum S (300-600 m) in the Catalan Sea. We found that the abundance of Etmopterus spinax decreased with decreasing $\mathrm{O}_{2}$ at the LIW core. E. spinax has strong swimming capacity compared to other bathyal sharks, having, for example, a more pelagic diet than Galeus melastomus (Relini-Orsi \& Wurtz 1977), and lower catchability with trawls of low vertical height (Cartes et al. 2009b). In addition, marine elasmobranchs maintain serum osmolarity similar to that of their surrounding seawater (Pang et al. 1977), a different strategy than that found among bony fishes with a blood osmolarity one-third below that of seawater (Pang et al. 1977). Thus, there must be a different pattern of acclimation to changes in environmental S by elasmobranchs and teleosts, with an apparently lesser capacity of the former to regulate the osmolarity of internal fluids. Maintaining an inner osmotic balance after small changes at LIW could imply a high energy cost for some sharks.

The response of sharks (e.g. Etmopterus spinax, Dalatias licha) to these changes in the LIW was not the same as that of Aristaeomorpha foliacea. E. spinax was a dominant species on the Balearic slope 40 yr ago (Maurin 1968). Both E. spinax and D. licha were still (relatively) abundant until the 1970s, while the extinction of $A$. foliacea occurred at the end of the 1960s (Cartes et al. 2011a). Large E. spinax are found in the western Mediterranean to $1400 \mathrm{~m}$, below depths of highest $\mathrm{S}$ (and of fishery pressure). This can contribute to explaining why the decline of E. spinax occurred later than that of the shrimp. In any case, the influence of the fishery effort seems unlikely to be the only cause of the decline in abundance of sharks over the slope of the Balearic Basin. In other regions of the western Mediterranean submitted to strong fishery pressure (e.g. around 470 vessels operating in the Sicily Channel: Fiorentino 2009), E. spinax is still a dominant species (Table 3). The

Table 3. Relative abundance $(\mathrm{N})$ and rank occupied by chondrichthyans in deep-sea fish assemblages in 3 areas of the western Mediterranean at depths between 400 and $800 \mathrm{~m}$ (between 200 and $800 \mathrm{~m}$ in the Tyrrhenian Sea and Sicily Channel). Data from 1994-2009 (to 2005 in the Alboran Sea). Abundance in ind. $\mathrm{h}^{-1}$ in the Alboran Sea. Rank of Galeus melastomus in the Sicily Channel based on F. Fiorentino (pers. comm.)

\begin{tabular}{|c|c|c|c|}
\hline Rank & Species & $\mathrm{N}$ & $\%$ \\
\hline \multicolumn{4}{|c|}{ Alboran Sea } \\
\hline 1 & Galeus melastomus & 3050.6 & 84.2 \\
\hline 7 & Etmopterus spinax & 376.7 & 10.4 \\
\hline 15 & Chimaera monstrosa & 80.3 & 2.2 \\
\hline 16 & Galeus atlanticus & 83.8 & 2.3 \\
\hline 28 & Scyliorhinus canicula & 18.8 & 0.5 \\
\hline 30 & Dalatias licha & 7.6 & 0.2 \\
\hline \multirow[t]{7}{*}{41} & Centrophorus uyato & 2.7 & 0.1 \\
\hline & Oxynotus centrina & 1.6 & 0.04 \\
\hline & Galeorhinus galeus & 0.2 & 0.005 \\
\hline & Heptranchias perlo & 0.2 & 0.005 \\
\hline & Raja circularis & 0.3 & 0.009 \\
\hline & Torpedo nobiliana & 1.3 & 0.034 \\
\hline & Torpedo marmorata & 0.3 & 0.007 \\
\hline Rank & Species & $\begin{array}{l}\text { Abundance } \\
\left(\mathrm{n} \mathrm{km}^{-2}\right)\end{array}$ & $\%$ \\
\hline \multicolumn{4}{|c|}{ Tyrrhenian Sea } \\
\hline 3 & Galeus melastomus & 397.1 & 87.0 \\
\hline \multirow[t]{5}{*}{6} & Etmopterus spinax & 56.0 & 12.3 \\
\hline & Chimaera monstrosa & 1.5 & 0.3 \\
\hline & Scyliorhinus canicula & 0.8 & 0.2 \\
\hline & Dalatias licha & 0.8 & 0.2 \\
\hline & Centrophorus uyato & 0.2 & 0.05 \\
\hline Rank & Species & $\begin{array}{l}\text { Abundance } \\
\left(\mathrm{n} \mathrm{km}^{-2}\right)\end{array}$ & $\%$ \\
\hline \multicolumn{4}{|c|}{ Sicily channel } \\
\hline \multirow[t]{8}{*}{1} & Galeus melastomus & 2866.9 & 95.8 \\
\hline & Scyliorhinus canicula & 58.9 & 2.0 \\
\hline & Etmopterus spinax & 51.0 & 1.7 \\
\hline & Chimaera monstrosa & 12.9 & 0.4 \\
\hline & Dalatias licha & 1.4 & 0.05 \\
\hline & Centrophorus uyato & 1.2 & 0.04 \\
\hline & Heptranchias perlo & 0.4 & 0.01 \\
\hline & Galeorhinus galeus & 0.5 & 0.02 \\
\hline
\end{tabular}


responses of populations of a given species living in different regions (e.g. in the Alboran and Tyrrhenian seas) to similar changes in habitat conditions may vary depending upon the specificity of their regional adaptations.

In conclusion, we suggest that small changes in the hydrological conditions $\left(\mathrm{T}, \mathrm{S}\right.$, and dissolved $\mathrm{O}_{2}$ ) of deep-water masses since the 1950s in the generally stable environment of the deep Balearic Basin have contributed to some significant changes in fish and crustacean assemblages. Sharks (especially Etmopterus spinax) would be the clearest examples of a negative response to these changes.

Acknowledgements. This research was performed and financed within the framework of the MICYT project ANTROMARE (CTM2009-12214-C02-01-MAR). In addition to the multidisciplinary work performed in ANTROMARE, this approach was also possible thanks to the work performed in all previous projects/cruises cited above, from which data were compiled in this paper. We especially thank M. Vargas-Yáñez, IEO Málaga, Spain, who provided the MEDATLAS data used in our analyses. We also thank J. Moranta, IEO Palma de Mallorca, for providing data from hauls performed in 1996 off Mallorca and F. Maynou (ICM Barcelona) and M. Lebrato (Leibniz Institute of Marine Science, IFM-GEOMAR) for critical reading of the manuscript.

\section{LITERATURE CITED}

Anderson MJ, Gorley RN, Clarke KR (2008) PERMANOVA + for PRIMER: guide to software and statistical methods. PRIMER-E, Plymouth

Bas C, Morales E, Rubió C (1955) La pesca en España. I. Cataluña. Institut d'Investigacions Pesqueres, Barcelona

Bas C, Maynou F, Sarda F, Lleonart J (2003) Variacions demogràfiques a les poblacions d'espècies demersals explotades. Institut d'Estudis Catalans, Barcelona

Ben-Tuvia A (1973) Man-made changes in the eastern Mediterranean Sea and their effect on the fishery resources. Mar Biol 19:197-203

Béthoux JP, Gentili B (1999) Functioning of the Mediterranean Sea: past and present changes related to freshwater input and climate changes. J Mar Syst 20:33-47

Béthoux JP, Gentili J, Raunet J, Taillez D (1990) Warming trend in the western Mediterranean deep water. Nature 347:660-662

Béthoux JP, Durrieu de Madron X, Nyffeler F, Tailliez D (2002) Deep water in the western Mediterranean: peculiar 1999 and 2000 characteristics, shelf formation hypothesis, variability since 1970 and geochemical inferences. J Mar Syst 33-34:117-131

Capapé C (1985) Nouvelle description de Centrophorus granulosus (Schneider, 1801) (Pisces, Squalidae). Données sur la biologie de la reproduction et le régime alimentaire des spécimens des côtes tunisiennes. Bull Inst Natl Sci Tech Océanogr Pêche Salammbó 12:97-141

Carrassón M, Cartes JE (2002) Trophic relationships in a Mediterranean deep-sea fish community: partition of food resources, dietary overlap and connections within the benthic boundary layer. Mar Ecol Prog Ser 241:41-55

Carrassón M, Stefanescu C, Cartes JE (1992) Diets and bathymetric distributions of two bathyal sharks of the Catalan deep sea (western Mediterranean). Mar Ecol Prog Ser 82:21-30

Cartes JE (1994) Influence of depth and season on the diet of the deep-water aristeid Aristeus antennatus along the continental slope (400 to $2300 \mathrm{~m}$ ) in the Catalan Sea. Mar Biol 120:639-648

> Cartes JE, Sardà F, Company JB, Lleonart J (1993) Daynight migrations by deep-sea decapod crustaceans in experimental samplings in the Western Mediterranean Sea. J Exp Mar Biol Ecol 171:63-73

> Cartes JE, Maynou F, Morales-Nin B, Massutí E, Moranta J (2001) Trophic structure of a bathyal benthopelagic boundary layer community south of the Balearic Islands (southwestern Mediterranean). Mar Ecol Prog Ser 215: 23-35

Cartes JE, Maynou F, Sardà F, Company JB, Lloris D, Tudela S (2004) The Mediterranean deep-sea ecosystems: an overview of their diversity, structure, functioning and anthropogenic impacts with a proposal for conservation. WWF/IUCN, Rome and Málaga

Cartes JE, Maynou F, Fanelli E, Papiol V, Lloris D (2009a) Long-term changes in the composition and diversity of deep-slope megabenthos and trophic webs off Catalonia (Western Mediterranean): Are trends related to climatic oscillations? Prog Oceanogr 82:32-46

Cartes JE, Maynou F, Lloris D, Gil de Sola L, García M (2009b) Influence of trawl type on the composition, abundance and diversity estimated for deep benthopelagic fish and decapod assemblages off the Catalan coasts (western Mediterranean). Sci Mar 73:725-737

Cartes JE, Maynou F, Fanelli E (2011a) Nile damming as plausible cause of extinction and drop in abundance of deep-sea shrimp in the western Mediterranean over broad spatial scales. Prog Oceanogr 91:286-294

> Cartes JE, Maynou F, Abelló P, Emelianov M, Gil de Sola L, Solé M (2011b) Long-term changes in the abundance and deepening of the deep-sea shrimp Aristaeomorpha foliacea in the Balearic Basin: relationships with hydrographic changes at the Levantine Intermediate Water. J Mar Syst 88:516-525

Cintra-Buenrostro C, Foster MS, Meldahl KH (2002) Response of nearshore marine assemblages to global change: a comparison of molluscan assemblages in Pleistocene and modern rhodolith beds in the southwestern Gulf of California, México. Palaeogeogr Palaeoclimatol Palaeoecol 183:299-320

Clarke KR, Ainsworth M (1993) A method of linking multivariate community structure to environmental variables. Mar Ecol Prog Ser 92:205-219

Clarke KR, Warwick RM (1995) Changes in marine communities: an approach to statistical analysis and interpretation. Natural Environment Research Council, Plymouth

> Coelho R, Erzini K (2008) Life history of a wide-ranging deepwater lantern shark in the north-east Atlantic, Etmopterus spinax (Chondrichthyes: Etmopteridae), with implications for conservation. J Fish Biol 73:1419-1443

> Dulvy NK, Baum JK, Clarke S, Compagno LJV and others (2008a) You can swim but you can't hide: the global status and conservation of oceanic pelagic sharks and rays. Aquat Conserv 18:459-482

Dulvy NK, Rogers SI, Jennings S, Stelzenmüller V, Dye SR, 
Skjoldal HR (2008b) Climate change and deepening of the North Sea fish assemblage: a biotic indicator of warming seas. J Appl Ecol 45:1029-1039

Emelianov M, Font J, Turiel A, Millot C and others (2006) Transformation of Levantine Intermediate Water tracked by MEDARGO floats in the western Mediterranean. Ocean Sci 2:281-290

Ferretti F, Myers RA, Serena F, Lotze HK (2008) Loss of large predatory sharks from the Mediterranean Sea. Conserv Biol 22:952-964

Fiorentino F (2009) La situazione delle risorse ittiche nelle aree di pesca siciliane ed il contributo delle scienze della pesca per un nuovo sviluppo sostenibile. Rapporto Annuale sulla Pesca e sull'Acquacoltura in Sicilia 2009. Osservatorio della Pesca dell Mediterraneo, p 77-109

Font J (1987) The path of the Levantine intermediate water to the Alboran sea. Deep Sea Res A 34:1745-1755

$>$ Fosså JH, Mortensen PB, Furevik DM (2002) The deepwater coral Lophelia pertusa in Norwegian waters: distribution and fishery impacts. Hydrobiologia 471:1-12

Gage JD, Tyler PA (1991) Deep-sea biology: a natural history of organisms at the deep-sea floor. Cambridge University Press, Cambridge

Galil BS (2004) Exotic species in the Mediterranean Sea and pathways of invasion. In: Davenport J, Davenport JL (eds) The effects of human transport on ecosystems: cars and planes, boats and trains. Royal Irish Academy, Dublin, p 1-14

Ghidalia W, Bourgois F (1961) Influence de la témperature et de l'éclairement sur la distribution des crevettes des moyennes et grandes profondeurs. Studies and Reviews 16. General Fisheries Commission for the Mediterranean, FAO, Rome

Gordon JDM, Bergstad OA (1992) Species composition of demersal fish in the Rockall Trough, north-eastern Atlantic, as determined by different trawls. J Mar Biol Assoc UK 72:213-230

Hopper AG (1995) Deep-water fisheries of the North Atlantic oceanic slope. Kluwer Academic Publishers, Dordrecht

Hutchings JA, Myers RA (1994) What can be learned from the collapse of a renewable resource? Atlantic Cod, Gadus morhua, of Newfoundland and Labrador. Can J Fish Aquat Sci 51:2126-2146

Koslow JA (1997) Seamounts and the ecology of deep-sea fisheries. Am Sci 85:168-176

- Kosnik MA (2005) Changes in Late Cretaceous-early Tertiary benthic marine assemblages: analyses from the North American coastal plain shallow shelf. Paleobiology 31:459-479

Kress N, Herut B (2001) Spatial and seasonal evolution of dissolved oxygen and nutrients in the Southern Levantine Basin (Eastern Mediterranean Sea): chemical characterization of the water masses and inferences on the $\mathrm{N}$ : $P$ ratios. Deep-Sea Res I 48:2347-2372

Legendre P, Legendre L (1998) Numerical ecology. Elsevier, Amsterdam

López-Jurado JL, Marcos M, Monserrat S (2008) Hydrographic conditions during the IDEA project (2003-2004). J Mar Syst 71:303-315

Margalef R (1985) Key environments: western Mediterranean. Pergamon Press, Oxford

Mariotti A, Struglia MV, Zeng N, Lau KM (2002) The hydrological cycle in the Mediterranean region and implications for the water budget of the Mediterranean Sea. J Clim 15:1674-1690
Massutí M (1971) Evolution de la pêche sur le talus du plateau continental des îles Baléares entre 1940 et 1969. Studies and Reviews 49. General Fisheries Commission for the Mediterranean, FAO, Rome

Matallanas J (1975) Contribución al estudio de la ictiofauna de las costas catalanas. Ictiofauna de la mar de Blanes (Gerona). PhD thesis, Universidad Autónoma de Barcelona

Matallanas J (1982) Feeding habits of Scymnorhinus licha in Catalan waters. J Fish Biol 20:155-163

Matallanas J, Moreno-Amich R (1985) Els peixos del Mar Català a les colleccions de la Universitat Autònoma de Barcelona. Bull Inst Cat Hist Nat 52(Secc Zool 6):169-196

Maurin C (1968) Ecologie ichthyologique des fonds chalutables atlantiques (de la baie ibero-maroccaine à la Mauritanie et de la Méditerranée Occidentale). Rev Trav Inst Pêch Marit 32:1-147

- Maynou F, Sbrana M, Sartor P, Maravelias C and others (2011) Estimating trends of population decline in longlived marine species in the Mediterranean Sea based on fishers' perceptions. PLoS ONE 6:e21818

Merrett NR, Gordon JDM, Stehman M, Headrich RL (1991) Deep demersal fish assemblage structure in the Porcupine Seabight (eastern North Atlantic): slope sampling by three different trawls compared. J Mar Biol Assoc UK 71:329-358

> Molinero JC, Ibanez F, Souissi S, Chifflet M, Nival P (2005) Phenological changes in the Northwestern Mediterranean copepods Centropages typicus and Temora stylifera linked to climate forcing. Oecologia 145:640-649

Moranta J (2007) Deep western Mediterranean demersal fish communities. PhD thesis, Universitat de les Illes Balears, Palma de Mallorca

Moranta J, Quetglas A, Massutí E, Guijarro B, Díaz P (2008) Spatio-temporal variations in deep-sea demersal communities off the Balearic Islands (western Mediterranean). J Mar Syst 71:346-366

> Myers RA, Worm B (2005) Extinction, survival or recovery of large predatory fishes. Philos Trans R Soc Lond B Biol Sci 360:13-20

Nielsen JN (1912) Hydrography of the Mediterranean and adjacent waters. In: Report of the Danish oceanographic expedition 1908-1910 to the Mediterranean and adjacent waters. Copenhagen, p 77-192

Oliver M (1953) Bionomía de los fondos de 300 a $600 \mathrm{~m}$ en el sur y suroeste de Mallorca. Bol Inst Esp Oceanogr 63: $1-21$

Pang PKT, Griffith RW, Atz JW (1977) Osmoregulation in elasmobranchs. Am Zool 17:365-377

Papiol V, Cartes JE, Fanelli E, Rumolo P (2013) Trophic web structure and seasonality of slope megafauna of the NW Mediterranean elucidated by stable isotope analyses: relationship with available food sources. J Sea Res (in press)

Pérès JM (1985) History of the Mediterranean biota and the colonization of depths. In: Margalef R (ed) Key environments: western Mediterranean. Pergamon Press, Oxford, p 198-232

Polunin NVC, Morales-Nin B, Pawsey WE, Cartes JE, Pinnegar JK, Moranta J (2001) Feeding relationships in Mediterranean bathyal assemblages elucidated by stable nitrogen and carbon isotope data. Mar Ecol Prog Ser 220:13-23

Por FD (1971) One hundred years of Suez Canal-a century of Lessepsian migration: retrospect and viewpoints. Syst 
Biol 20:138-159

Relini-Orsi L, Wurtz M (1977) Patterns and overlap in the feeding of two selachians of bathyal fishing grounds in the Ligurian Sea. Rapp P-V Reun Comm Int Explor Sci Mer Médit 24:89-93

Rixen M, Beckers JM, Levitus S, Antonov J and others (2005) The western Mediterranean deep water: a new proxy for global climate change. Geophys Res Lett 32: L12608, doi:10.1029/2005GL022702

Roether W, Well R (2001) Oxygen consumption in the Eastern Mediterranean. Deep-Sea Res I 48:1535-1551

Rohling EJ, Bryden HL (1992) Man induced salinity and temperature increase in the western Mediterranean deep water. J Geophys Res 97C:191-198

Segura M (2007) Relació entre la distribució de nutrients i oxigen dissolt i la composició elemental del fitoplancton a la Mar Catalana (NO Mar Mediterrània). PhD thesis, Universitat Politècnica de Catalunya, Barcelona

Skliris N, Lascaratos A (2004) Impacts of the Nile River damming on the thermohaline circulation and water mass characteristics of the Mediterranean Sea. J Mar

Editorial responsibility: Geir Ottersen,

Oslo, Norway
Syst 52:121-143

Spanier E, Galil BS (1991) Lessepsian migration: a continuous biogeographical process. Endeavour 15:102-106

Suau P (1981) Campaña Mediterráneo II (marzo 1977). Datos Informativos Ser 8. Instituto de Investigaciones Pesqueras, CSIC, Barcelona

Ter Braak CJF (1986) Canonical correspondence analysis: a new eigenvector technique for multivariate direct gradient analysis. Ecology 67:1167-1179

$>$ Ter Braak CJF, Verdonschot PFM (1995) Canonical correspondence analysis and related multivariate methods in aquatic ecology. Aquat Sci 57:255-289

Tortonese E (1956) Leptocardia, Ciclostomata, Selachi. Fauna d'Italia 2. Calderini, Bologna

- Vargas-Yáñez M, Moya F, Tel E, García-Martínez MC, Guerber E, Bourgeon M (2009) Warming and salting in the western Mediterranean during the second half of the 20th century: inconsistencies, unknowns and the effect of data processing. Sci Mar 73:7-28

> Williams N (1998) The Mediterranean beckons to Europe's oceanographers. Science 279:483-484

Submitted: March 9, 2012; Accepted: September 12, 2012 Proofs received from author(s): January 25, 2013 